\title{
AN EVALUATION OF CHINA'S CARBON EMISSION REDUCTION POLICIES ON URBAN TRANSPORT SYSTEM
}

\author{
Hou Jiaru* \\ Feng Xiangzhao**
}

\begin{abstract}
Climate change has become one of the hottest issues in $\checkmark$ international law. As the world's second-largest greenhouse gas emission sector, the transport sector, especially the urban traffic system, is facing much more pressure to reduce its aggregate emissions. This article begins with a theoretical examination of the system theory, takes the cobenefit concept as a methodological guide and discusses various urban traffic emission reduction policies such as travel demand management, vehicles policies, fuel policies, road policies and comprehensive management policies of the urban transport system. It argues that holistic policy reform is the most important means of promoting $\mathrm{CO}_{2}$ emission reduction effectively in urban traffic system. It is unrealistic to only implement one type of policy to achieve $\mathrm{CO}_{2}$ emission reduction targets in urban traffic system; a policy mix will arguably be of great significance to achieve and sustain emission reduction. Therefore, the promotion and perfection of policy system of $\mathrm{CO}_{2}$ emission reduction in urban traffic system and the intensification of policy innovation should be deemed a strategic choice to effectively realize $\mathrm{CO}_{2}$ emission reduction targets in urban traffic system, while promoting the sustainable development of the urban traffic system, the city and the economy.
\end{abstract}

Keywords: Urban transport system, greenhouse gas emission reduction, policy summarizing.

doi: http://dx.doi.org/10.4314/jsdlp.v6i1.2

* Hou Jiaru, LLM (Vermont), PhD (Remin), Professor at Civil, Commercial \& Economic Law School, China University of Political Science and Law, Beijing.

* Corresponding author: Feng Xiangzhao, PhD in economics, Associate Professor, currently serves at Climate Change Research Department, Policy Research Center for Environment and Economics of the Ministry of Environmental Protection, Beijing, China. Email: feng.xiangzhao@prcee.org.

The article is supported by Program for Young Innovative Research Team in China University of Political Science and Law. 


\section{INTRODUCTION}

$A$ t present, climate change, characterized mainly by global warming, international community. ${ }^{1}$ As the world's second largest greenhouse gas (GHG) emission sector, the transportation sector contributed 7 billion metric tonnes of $\mathrm{CO}_{2}$ emissions in 2011, accounting for about 22 per cent of the global total emission of $\mathrm{CO}_{2}$ produced by fossil fuel use. This is second only to the 38 per cent produced by the power and heat supply sector. ${ }^{2}$ In the all subsectors of the transportation system, the largest contributor of $\mathrm{CO}_{2}$ emission was road traffic. In 2011, for example, the $\mathrm{CO}_{2}$ emission from road traffic was 5.17 billion tonnes, accounting for about 74 per cent of the total emission of the whole traffic sector. ${ }^{3}$ So far, although many countries have developed $\mathrm{CO}_{2}$ emission reduction policies and measures for road transportation, such policy changes have remained unable to halt the steady rise of $\mathrm{CO}_{2}$ emissions in the sector.

For China, along with the rapid development of the economy and urbanization, as well as the continuous increase in residents' income, the geometric rise of motorization, traffic demand and traffic energy use, are posing increased environmental concerns. The negative external effects of emissions and pollution from urban traffic systems are evident in the steady rise in annual greenhouse gas emissions. Petroleum-based fuel is dominating energy sources consumption structure of the road traffic sector. China's petroleum external dependency climbed to 58 per cent in 2013 from 6 per cent in 1993 when it became a net oil importer. From 1990-2011, $\mathrm{CO}_{2}$ emission in the road traffic sector increased by 752.8 per cent, far higher than the growth rate of 473.6 per cent recorded in the whole traffic sector during the same period. In 2011, China's $\mathrm{CO}_{2}$ emissions increased to 7.954 billion tonnes, accounting for about a quarter

1 Global warming and climate change are terms for the observed century-scale rise in the average temperature of the Earth's climate system and its related effects. More and more scientific evidences show that the climate system is warming. The Intergovernmental Panel on Climate Change (IPCC) reported in 2014 that scientists were more than 95 per cent certain that global warming is being caused mostly by increasing concentrations of greenhouse gases and other human (anthropogenic) activities.

2 International Energy Agency (IEA), CO2 Emissions from Fuel CombustionÿIEA, Paris, 2013).

3 Feng Xiangzhao, ZouJi and Xu Guangqing, "Economic Study on China's Fuel Economy Standard” (2008) 6 Environmental Protection 23-26. 
of total global emissions. Road traffic is one of the areas with the fastest growth of $\mathrm{CO} 2$ emission in China. ${ }^{4}$ At the local level, especially in urban areas, the results are serious traffic congestion, deteriorating air quality and the continuously rising traffic accident rate.

In this context, some policies and measures for correcting the negative externalities of the traffic sector have been adopted and implemented. However, due to the division of the function of the central government and local government, the policies focus on different aspects. While policies developed or issued by the central government are designed to ensure the security of vehicle energy supplies and the reduction of $\mathrm{CO}_{2}$ emissions, policies developed by local governments start mainly from the control of atmospheric pollution and urban traffic congestion. The result is the proliferation of different standards, policies and regulations across central and local government levels with little coherence and coordination.

This article discusses the need for a more coherent and holistic policy reform to address the impacts of urban traffic system GHG emissions in China. Based on systems theory, this article examines city traffic as a complex system that consists of five basic elements: people, vehicles, fuel, road and traffic systems management. Consequently, the article divides the urban traffic greenhouse gas emission reduction strategy into five kinds of policies to be investigated, respectively. They are travel demand management, vehicle policies, fuel policies, road policies and urban transportation comprehensive management.

This article is in four sections. After this introduction, section two discusses the systems theory as a theoretical and analytical basis for a policy reform of the urban traffic system to ensure legislative and policy coherence. Section three evaluates the effectiveness of recent policy measures developed to halt the rise of GHG emissions in urban traffic systems in China. It discusses key strengths and areas that call for rethink and reform. The article concludes in section four.

\section{THE SYSTEMS THEORY: ANALYTICAL FRAMEWORK}

The analytical framework of this article is constructed based on the systems theory and synergy method (see Figure 1). The high level of

4 Feng Xiangzhao, Study on Greenhouse Gases Emission Reduction Strategy of Urban Transport System (Meteorological Press, Beijing: China 2009). 
$\mathrm{CO}_{2}$ emission in the urban traffic system is a result of multiple factors including traffic demand, traffic structure, traffic energy consumption intensity and fuel type. Thus, to achieve $\mathrm{CO}_{2}$ emission reduction targets for urban traffic, we must not only focus on the five elements of urban traffic system (that is, the people, roads, vehicles, fuel, and system management mechanism) to develop various policies, respectively. There is also a need to take the whole traffic system as the object of action to develop corresponding emission reduction strategies and promote the low carbon development of the urban road traffic system through technology changes and combined drives of all kinds of policies.

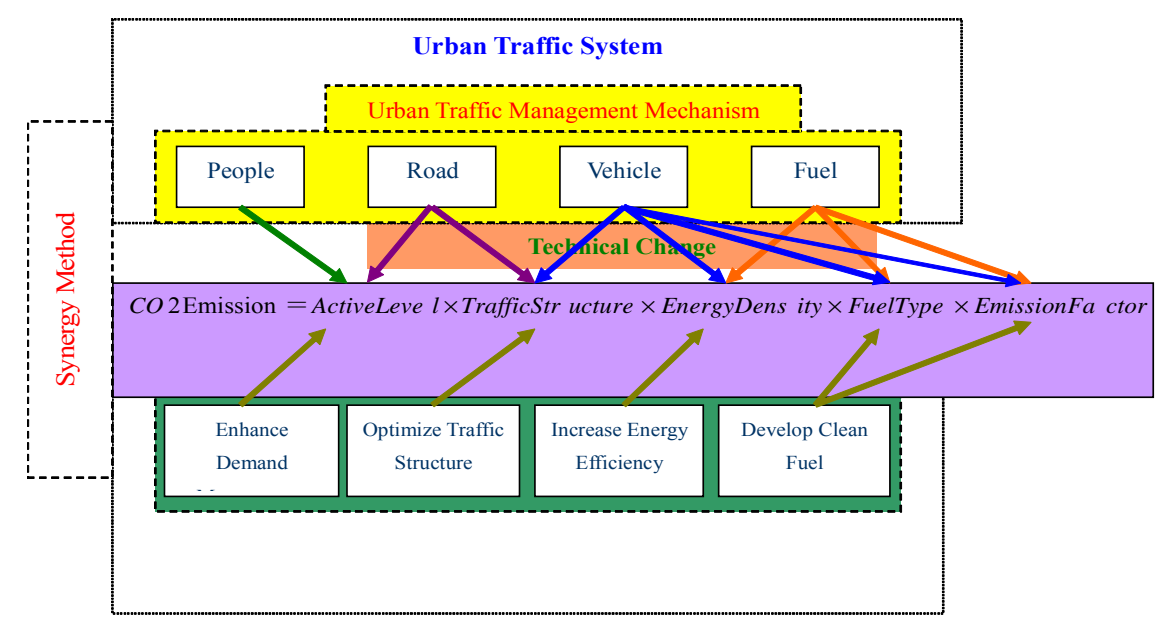

Figure 1. Analysis Framework

In particular, synergy method has now been widely used in the research field of climate change. The so-called synergy refers to the implementation of a single policy or a combination of policies that can produce two or more profits, and these benefits may be unexpected, namely, that the decision maker does not expect them when it issues a particular policy for a particular purpose, and with the execution of the policy it is found that the policy can generate additional benefits. ${ }^{5}$ In this study, the improvement of air quality, the mitigation of traffic congestion,

5 Cai Bofeng and Feng Xiangzhao, "Low-carbon Policies and Actions in China's Transport Sector” (2011) Environmental Economy 10:38-45. 
the security of energy supply and the sustainability of development are all the synergies of $\mathrm{CO}_{2}$ emission reduction strategy in the urban traffic system. Furthermore, the sustainable development of the urban traffic system, the whole city and even the whole country's traffic system, and the whole national economy are the most important synergies.

\section{THE CARBON EMISSION REDUCTION POLICIES OF THE URBAN TRAFFIC SYSTEM}

The five kinds of emission reduction policies regarding vehicle, road, vehicle fuel, travel demand and integrated management of traffic system are discussed in the following sub-sections:

\subsection{Vehicle-Based Emission Reduction Policies}

Addressing vehicle-based emissions is one of the core elements of road traffic low-carbon development. At present, many countries and regions have introduced different measures to limit ownership and reduce the use of motor vehicles so as to lessen the increasingly severe environmental pressure caused by the growth of motor vehicle ownership. For example, Singapore and Shanghai have introduced motor vehicle quota system, and most countries have adopted inhibitory fiscal and taxation policies like imposing high purchase tax and registration fee (see Table 1). Also, in order to control the fuel consumption of motor vehicles, there are at least nine countries or regions worldwide that are currently running or have already submitted the relevant fuel economy standards, such as America's CAFÉ (Corporate Average Fuel Economy Standards) and Japan's Top-Runner Program. ${ }^{6}$

The next question is to examine the impacts of energy conservation and carbon emission reduction measures, using China's fuel economy standards and Shanghai's vehicle quota system as examples.

6 Wang Gang, Implementing Effective Traffic Demand Management - TDM in USA, Beijing: People’s Public Security University Press, 2004. 
Table 1: Major Policies of Emission Reduction in Terms of Vehicles at Home and Abroad

\begin{tabular}{|c|c|c|c|c|}
\hline Category & $\begin{array}{l}\text { Title of the } \\
\text { Policy }\end{array}$ & $\begin{array}{l}\text { Implementa- } \\
\text { tion Level }\end{array}$ & \begin{tabular}{|l} 
Foreign \\
Practices
\end{tabular} & $\begin{array}{l}\text { Has China } \\
\text { Adopted? }\end{array}$ \\
\hline \multirow[t]{5}{*}{$\begin{array}{l}\text { Order and } \\
\text { Control }\end{array}$} & $\begin{array}{l}\text { Speed limit } \\
\text { on high-speed } \\
\text { trunk road }\end{array}$ & City & \begin{tabular}{|l} 
Major \\
developed \\
countries \\
\end{tabular} & Yes \\
\hline & $\begin{array}{l}\text { Fuel economy } \\
\text { standards }\end{array}$ & Country & $\begin{array}{l}\text { Japan, EU, } \\
\text { USA, Cana- } \\
\text { da, Australia, } \\
\text { South Korea } \\
\text { and Taiwan }\end{array}$ & $\begin{array}{l}\text { Yes, issued in } \\
2004, \text { stage I } \\
\text { standard was } \\
\text { executed in } \\
2005, \text { stage III } \\
\text { standard will } \\
\text { be executed in } \\
2015 .\end{array}$ \\
\hline & $\begin{array}{l}\text { Vehicle I/M } \\
\text { system }\end{array}$ & Country & $\begin{array}{l}\text { Almost all } \\
\text { the countries }\end{array}$ & Yes \\
\hline & $\begin{array}{l}\text { License plate } \\
\text { auction system } \\
\text { / Purchase lim- } \\
\text { itation lottery } \\
\text { system }\end{array}$ & $\begin{array}{l}\text { City (or } \\
\text { country) }\end{array}$ & Singapore & \begin{tabular}{|l} 
Shanghai, \\
Beijing, \\
Guangzhou, \\
Guiyang
\end{tabular} \\
\hline & $\begin{array}{l}\text { Vehicle driv- } \\
\text { ing limitation } \\
\text { according to } \\
\text { odd and even } \\
\text { number }\end{array}$ & City & NA & Beijing, Wuhan \\
\hline \multirow[t]{5}{*}{$\begin{array}{l}\text { Fiscal and } \\
\text { Taxation } \\
\text { Measures }\end{array}$} & $\begin{array}{l}\text { Purchase tax } \\
\text { (VAT, con- } \\
\text { sumption tax } \\
\text { and registration } \\
\text { fee) }\end{array}$ & Country & $\begin{array}{l}\text { Almost all } \\
\text { the countries }\end{array}$ & Yes \\
\hline & $\begin{array}{l}\text { Energy saving } \\
\text { and new energy } \\
\text { vehicle purchase } \\
\text { tax concessions }\end{array}$ & $\begin{array}{l}\text { Country or } \\
\text { city }\end{array}$ & $\begin{array}{l}\text { Japan, USA, } \\
\text { Germany, } \\
\text { Denmark }\end{array}$ & Yes \\
\hline & $\begin{array}{l}\text { Vehicle sta- } \\
\text { tus-based annual } \\
\text { tax }\end{array}$ & Country & $\begin{array}{l}\text { EU, Singa- } \\
\text { pore }\end{array}$ & $\begin{array}{l}\text { Yes, vehicle } \\
\text { and vessel use } \\
\text { tax }\end{array}$ \\
\hline & $\begin{array}{l}\text { Clean and } \\
\text { fuel-efficient } \\
\text { official vehicles } \\
\text { reward system }\end{array}$ & $\begin{array}{l}\text { Country or } \\
\text { city }\end{array}$ & UK & No \\
\hline & Parking fee & City & All countries & Yes \\
\hline
\end{tabular}




\subsubsection{Vebicle Fuel Economy Standards}

At present, fuel economy standard has been recognized globally as one of the most effective means for controlling motor vehicle fuel consumption and emission. The actual fuel efficiency data of every country or region in the world before 2008 and the target limit of their fuel economy standards that will be implemented in the future are shown in Figure 2. It can be seen that the fuel efficiencies of passenger cars in the European Union and Japan are the highest, and their single vehicles $\mathrm{CO}_{2}$ emission levels are the lowest.

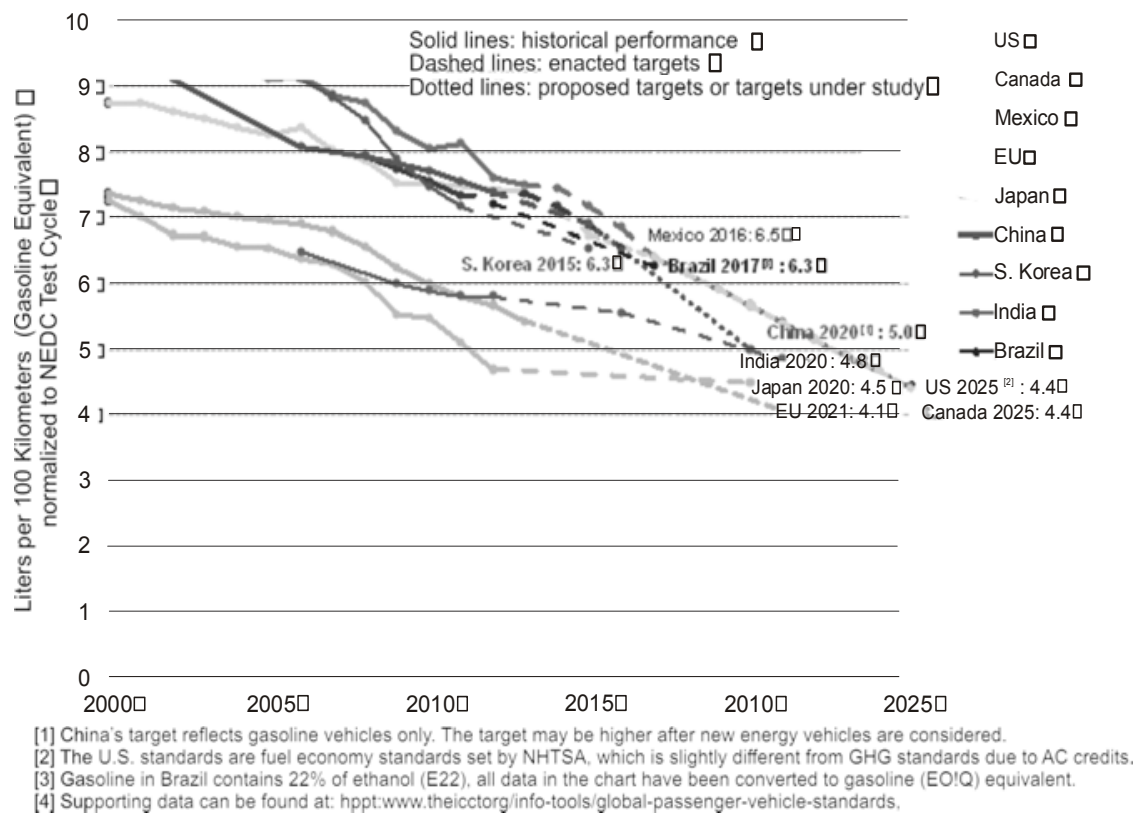

Figure 2. International Comparison of Fuel Economy Standard Towards Passenger Cars

*The Canada target value of 2016 showed in the figure is an estimate value other than an officially publicized value. The ordinate gives the fuel economy standard value for passenger car, or the average limit of fuel consumption, of which the unit is: 1/hundred kilometres (NEDC).

The Limits of Fuel Consumption for Passenger Cars GB19578-2004 implemented by China from 2005 has put forward fuel economy requirements for newly produced passenger cars. GB19578-2004 was implemented in two stages: the requirements of first stage were effective 
for new models of cars from 1 July 2005, and for the old models one year later. The requirements of second stage were effective for new models of cars from 1 January 2008, and for the old models one year later. On 19 July 2007, China released the standard of Limits of Fuel Consumption for Light Duty Commercial Vehicles, and it was implemented on 1 February 2008. After several years of the implementation of these standards, the total amount of gasoline saved reached 910,300 tonnes, diesel oil - 680,600 tonnes; that was equivalent to a reduction of 5.1494 million metric tonnes of $\mathrm{CO}_{2}$ emission.

Broadly speaking, China's current fuel economy standards include the testing method, the approval and publicity system, the identity management, the supervision mechanism and the supporting administration measures for rewards and punishments, etc., which correspond to the two standards. ${ }^{7}$ Among them, the Fuel Consumption Label for Light Vehicle has been implemented compulsively since 1 January 2010 in China to guide the public to choose energy saving and environmentally friendly models, and improve the environmental awareness of low carbon from the public.

In Figure 3, China's fuel economy target is converted into $\mathrm{CO}_{2}$

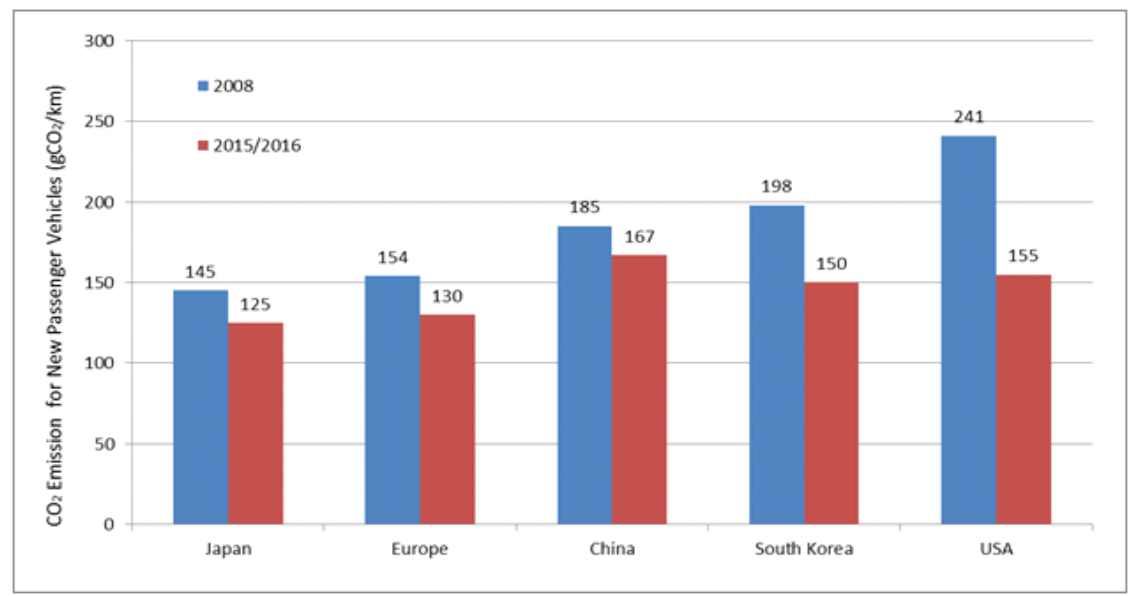

Figure 3. The Status Quo of $\mathrm{CO}_{2}$ Emission from Light Duty Vehicles in Major Countries of the World and Their Corresponding Control Target Note: The Chinese data came from the third stage of Limits of Fuel Consumption for Passenger Cars promulgated in December 2011. The new standard is expected to be officially executed in 2015, when the country's average new passenger car fuel consumption will fall to about $7 \mathrm{~L} / 100 \mathrm{~km}$ with $\mathrm{CO}_{2}$ emission to $167 \mathrm{~g} / \mathrm{km}$.

7 World Bank, World Development Report 2010: Development and Climate Change (World Bank, 2009) available at <www.cemt.org/events/Justpub/justCO2.htm>, accessed 2 October 2015. 
emissions standards and is compared with the international standards. It can be seen that the developed countries have made great efforts to control vehicle $\mathrm{CO}_{2}$ emissions. The biggest drop in $\mathrm{CO}_{2}$ emission is found in the USA, while China's 2015 goals, compared to that of developed countries, still have a distance to cover

\subsubsection{Shanghai's Vebicle Quota System}

So far, Shanghai is the first city in China to implement the policy of private car licence plate auction. ${ }^{8}$ Since 1994 , it began to control the total quantity of new private cars in the downtown of the city by way of bidding and auction. ${ }^{9}$ In 2000, Shanghai Municipal People's Congress passed the Regulations on the Administration of Motor Vehicles in Shanghai. ${ }^{10}$ According to the regulations, since January 2001, Shanghai has been implementing unreserved public auction of motor vehicle licence plates (see the following table); hence citizens, legal persons and other organizations in Shanghai could only obtain the car licence plate through bidding (auction) after they have bought cars. ${ }^{11}$

As the economic centre and financial centre of China, because of the implementation of the licence plate auction system, Shanghai's private vehicle ownership remains low, compared with Beijing, which virtually saved the vehicle fuel and reduced the emissions of all kinds of conventional pollutants and $\mathrm{CO}_{2}$ caused by vehicle fuel combustion.

Table 2. Main Effects of the Car Licence Plate Auction System Implemented in Shanghai

\begin{tabular}{ll}
\hline \multicolumn{1}{c}{ Main Effects } & \multicolumn{1}{c}{ Brief } \\
\hline Motor vehicle & $\begin{array}{l}\text { As the economic centre and financial centre of China, } \\
\text { ownership }\end{array}$ \\
keeps s a result of the implementation of the licence plate \\
growth & $\begin{array}{l}\text { auction system, Shanghai's private vehicle ownership } \\
\text { stays all along at a lower level compared with Beijing. }\end{array}$ \\
& $\begin{array}{l}\text { According to the data of National Bureau of Statistics, } \\
\text { by the end of 2009, Shanghai's private motor vehicle }\end{array}$ \\
& $\begin{array}{l}\text { ownership was only about 850,300, while that of } \\
\text { Beijing was 2,965,600, equivalent to 3.5 times that of } \\
\text { Shanghai. }\end{array}$
\end{tabular}

8 Feng Xiangzhao (n 4).

9 ibid.

10 ibid.

11 ibid. 


\begin{tabular}{|c|c|}
\hline $\begin{array}{l}\text { Improved } \\
\text { traffic } \\
\text { congestion }\end{array}$ & $\begin{array}{l}\text { According to the Annual Report on Expedite Indexes } \\
\text { in China's Cities 2006, the job commuting time in } \\
\text { Shanghai was } 36 \text { minutes and the average driving speed } \\
\text { was } 26.9 \mathrm{~km} / \mathrm{h} \text {, slightly better than Beijing in traffic } \\
\text { congestion, while the two indicators in Beijing were } 43 \\
\text { minutes and } 26.6 \mathrm{~km} / \mathrm{h} \text {, respectively. Judging from the } \\
\text { development of Shanghai traffic, despite that the licence } \\
\text { plate auction cannot solve the fundamental problems of } \\
\text { congestion, it delayed the mechanization process of } \\
\text { Shanghai, inhibited the deterioration of traffic } \\
\text { congestion, and gained precious time for the city to } \\
\text { construct rail transit. }\end{array}$ \\
\hline $\begin{array}{l}\text { Raised the } \\
\text { public traffic } \\
\text { construction } \\
\text { funds }\end{array}$ & $\begin{array}{l}\text { Shanghai began to implement total amount control } \\
\text { policy for new private car through quota bidding in } \\
\text { downtown area in } 1994 \text {. Between then and June } 2004 \text {, it } \\
\text { obtained RMB4.05 billion yuan of auction revenue. } \\
\text { During this time, public spending was allocated } \\
\text { RMB3.93billion yuan, which RMB2.5 billion yuan was } \\
\text { used for middle ring road construction, RMB1.2 billion } \\
\text { yuan for rail transit construction, RMB230 million } \\
\text { yuan for road traffic equipment and facilities } \\
\text { construction, and the over RMB100 million yuan } \\
\text { remaining was reserved in the special account of } \\
\text { municipal fiscal. }\end{array}$ \\
\hline $\begin{array}{l}\text { Benefited the } \\
\text { reduction of } \\
\text { greenhouse } \\
\text { gases emission }\end{array}$ & $\begin{array}{l}\text { The new car licence plate auction system has effectively } \\
\text { restrained the fast growth of car ownership, so that } \\
\text { fuel consumption can be reduced and thus reduce the } \\
\text { emissions of all kinds of conventional pollutants and } \\
\mathrm{CO}_{2} \text { caused by vehicle fuel combustion. It was } \\
\text { estimated that in } 2005 \text {, all private car commuters in } \\
\text { Beijing spent an additional fuel costs of about } \\
\text { RMB3.728 billion yuan because of the traffic } \\
\text { congestion, while that in Shanghai was } 791 \text { million } \\
\text { yuan. Private car commuters in Beijing have } \\
\text { contributed an additional annual CO2 emission of } \\
\text { about } 2.0827 \text { million tonnes because of the traffic } \\
\text { congestion, more than } 4.7 \text { times that in Shanghai (it was } \\
\text { only } 441,600 \text { tonnes in Shanghai). }\end{array}$ \\
\hline
\end{tabular}

Source: National Bureau of Statistics, 2010; Feng Xiangzhao, Zou Ji, et al., 2009. 


\subsection{Road-Based Emission Reduction Policies}

Abundant literature shows that, so far, no $\mathrm{CO}_{2}$ emission reduction policy is based on the city roads. Some road-based innovative traffic management measures are noteworthy, especially the city road congestion charges in Singapore, London and Stockholm, the rapidly developed HOV (high occupancy vehicle) and HOT (high occupancy toll lanes) policies in the United States and the BRT (bus rapid transit lanes) system in Curitiba (Brazil) and other cities. These policies are mainly designed to solve the problem of increasing serious traffic congestion in large and mediumsized cities, but in a broad sense, their implementation has shown positive significance for improving urban air quality and reducing $\mathrm{CO}_{2}$ emission.

In recent years in China, under the policy of "energy saving, emission reduction and lower carbon" and "prior development of public transport" policies, the infrastructure constructions such as BRT, subway and light rail have run into "fast track" in many cities in China.

\subsubsection{Bus Rapid Transit (BRT)}

BRT as remained one of the cheapest ways to develop a large capacity express system and obtain rapid development in China in recent years. Some studies show that compared to cars, buses, with large capacity have a dynamic road area possession per capita of 10:1. The CO, HC and NOx emissions of the former is seven times, 20 times and 10 times that of the latter, respectively, while the per capita external cost consumed, the noise, the accidents and the greenhouse effect of the former is 19 times of that of the latter. ${ }^{12}$ The average construction cost of the city BRT system at present in China is RMB 20 70 million yuan per kilometre. ${ }^{13}$ For example, Chongqing BRT's construction cost is RMB 29.48 million yuan per kilometre, which is equivalent only to one-tenth of the construction cost of light rail (RMB 280 million yuan $/ \mathrm{km}$ ) and one-sixteenth of that of the subway. So it is of greater cost advantage. ${ }^{14}$

On 16 and 17 April, 2005, the China BRT Action Conference was held in Shanghai. Mayors and their representatives in charge of BRT from 32 provinces and cities unified their thought of giving priority to the

12 Bofeng and Xiangzhao (n 5).

13 ibid.

14 Jiang Yulin, Wu Hongxiang and Shen Yun, Expedite, Effective, Safe and GreenAnalysis on Significant Problems of Sustainable Development of China's Urban Public Transport (Beijing: Science Press, 2010). 
development of BRT. A total of 13 cities initiated cooperation proposition and signed the Cooperation Agreement of BRT Cities Alliance (Shanghai Agreement). Five months later, the state council issued Notes on the Priority on the Development of City Public Traffic to six ministries and commissions. ${ }^{15}$

This programmatic document on BRT development clearly puts forward "developing big traffic fast bus system" and "safeguards the road using priority of public transportation". ${ }^{16}$ From 30 December the same year, China's first special bus rapid transit line was officially launched the whole lane of Beijing south axial BRT was put into use. ${ }^{17}$ So far, the cities that have BRT constructed and operated include Beijing, Guangzhou, Hangzhou, Suzhou, Zhengzhou, Dalian, Changzhou, Jinan, Zaozhuang, Hefei, Kunming, Xiamen, Chongqing, Yancheng and Urumqi. Other cities that are planning and constructing BRT include Wuhan, Nanchang, Changsha, Shenzhen, Shenyang and Lanzhou, among others. ${ }^{18}$ It is noteworthy that Chongqing BRT and Zhengzhou BRT have been successfully developed as CDM carbon reduction projects, with Chongqing being the first city domestically and the second city internationally involved in the bus area clean development mechanism (CDM). This kind of BRTCDM project can lead to a $\mathrm{CO}_{2}$ equivalent emission reduction of 218,000 tonnes a year on average and can realize the economic benefits of about USD 250,000 per year on average. ${ }^{19}$

\subsubsection{Rail Transit}

To alleviate urban traffic congestion and promote sustainable development of the urban traffic, in recent years, many large and medium-sized cities in China have planned and constructed the rail transit as the main framework of their comprehensive transportation system. The construction of rail transit has entered a new stage of rapid development.

Influenced by the energy saving and emission reduction efforts domestically and the financial crisis internationally, many cities started the building of the subway in August 2008. In 2009 alone, the state council approved 22 urban subway construction plans, with a total investment

15 Bofeng and Xiangzhao (n 5).

16 ibid.

17 ibid.

18 ibid.

19 ibid. 
of RMB 882.003 billion yuan. ${ }^{20}$ According to the statistics provided by Institute of Comprehensive Transportation of National Development and Reform Commission, up to the end of 2010, there are 41 cities of which the construction of rail transit has been approved or planed, among them, more than 90 per cent of provincial capital cities has developed rail transit plan, and 15 per cent of the cities specifically designated in the state plan and prefecture-level cities has developed rail transit plan. By the end of August 2011, China has completed 50 rail transit lines with a total distance of 1568 kilometres and 995 operating stations. ${ }^{21}$

Urban rail transit includes mainly the subway, light rail, magnetic levitation and tram. At present, cities which own rail transit in China are Beijing, Tianjin, Shanghai, Nanjing, Wuhan, Chongqing, Dalian, Changchun, Taipei, Kaohsiung, Xi'an, Hong Kong, Guangzhou and Shenzhen; another 36 cities have planned to construct urban rail transit and 28 of them have been approved by the state. According to the Comprehensive Transportation System Development Plan During "Twelfth Five-year" (Draft) drawn by Ministry of Transport, the total mileage of urban rail transit in China will reach 3000 kilometres in 2015, up 186.6 per cent from the 1372 kilometres at the end of $2010 .{ }^{22}$

\subsection{Fuel-Based Emission Reduction Policies Research}

Developing alternative fuels for vehicle and collecting fuel tax can be seen as two important fuel emission reduction policies. Among them, the development of alternative fuels for vehicle is considered to be an important strategic choice in the world to reduce $\mathrm{CO}_{2}$ emissions in the field of traffic. China has now basically established a policy system guided by national macro policy and supported by local specific policy to encourage the development of alternative fuels for vehicle and alternative fuel vehicles.

In addition to the clear strategic position of developing alternative fuels for vehicle in laws such as the Energy Conservation Law and Renewable Energy Law, the Chinese government has stressed several times the significance of alternative fuels for the development of low-

20 ibid.

21 IPCC, Climate Change 2007: Mitigation of Climate Change (Working Group III to the Fourth Assessment Report of the Intergovernmental Panel on Climate Change. Cambridge, UK and New York, USA: Cambridge University Press 2007).

22 World Bank, Expedite Cities: World Bank's Evaluation Report on Urban Traffic Strategy (China Financial and Economic Publishing House, Beijing 2006). 
carbon traffic in the development plans successively implemented. These include the Compendium of National Energy Medium and Long-term Development Plan for 2004-2020 which entered into the new century. In order to speed up the promotion and application of fuel ethanol, China promulgated two important standards, namely Denatured Fuel Ethanol GB18350-2001 and Ethanol Gasoline for Motor Vehicles GB18351-2001 in 2001.

Economic incentive policies, such as fiscal subsidies and all kinds of preferential tax policies, are also important choices for promoting the development of alternative fuels for vehicle. In June 2004, the Ministry of Finance issued Notice on Subsidies Policy for Loss on Fuel Ethanol, a series of tax and price policies the state implementing preferential subsidies for fuel ethanol production and use. Four specified fuel ethanol production enterprises were exempted from 5 per cent consumption tax, the value-added tax of producing fuel ethanol would be returned after tax and seasoned rice used in the production would be subsidized and given preferential prices. In addition, some local governments provided preferential income tax rate for enterprises producing alternative fuels for vehicle and gas stations selling alternative fuels for vehicle.

In addition, the fuel tax is arguably an important policy to effectively guide the consumers' reasonable vehicle fuel consumption, reduce road traffic energy consumption and reduce carbon emissions. In China, the fuel tax refers to surcharge on gasoline and diesel oil purchased and used by vehicles running within the territory of China. ${ }^{23}$ It is actually a consumption tax for oil product. Specifically, fuel tax implemented from 1 January 2009 cancelled six charges originally collected outside the product oil price, including the highway maintenance fees, the waterway maintenance fees, the road transport management fees, the road passenger and freight transport surcharges, the water transport management fees and the water passenger and freight shipping surcharge. The unit gasoline consumption tax amount increased by 0.8 yuan per litre, from RMB 0.2 yuan to RMB 1 yuan per litre, and unit diesel oil consumption tax rose by 0.7 yuan per litre, from RMB 0.1 yuan to 0.8 yuan per litre. ${ }^{24}$

23 Bofeng and Xiangzhao (n 5).

24 Zhang Quan, Hong Hao \& Lin Dande (eds), Green Travel Report During World Expo 2010 (Shanghai Science \& Technology Press 2011). 


\subsection{Travel Demand Management-Based Emission Reduction Policies}

Specifying and reasonably guiding consumers' travel demand is an important strategic choice of megacities policymakers at home and abroad to solve traffic problems (mainly congestion and air quality deterioration), decrease traffic energy consumption and reduce greenhouse gas emissions. Viewing various practices at home and abroad, it can be found that carpooling scheme, flexible schedule, ecological driving method, traffic subsidy system, parking charge system and transfer centre system can all be deemed as effective traffic demand management policies.

Due to actively advocating the concept of carpooling in the United States, car-sharing proportion in work travel became very high. For example, in 1980, 19 per cent of the work travel in United States is realized by carpooling. ${ }^{25}$

The main forms of flexible schedule in practice include staggered working hours, compressed weekly working days and flexible working hours. During the Beijing Summit of the Forum on China-Africa Cooperation in November 2006, for example, to ensure the meeting held smoothly, Beijing traffic management department asked all units of the city to reasonably adjust their working hours and stagger the traffic rush hour. The results show that the first day of the China-Africa Forum meeting, traffic flow declined visibly on Chang'an Avenue and Thirdring Road with cars being able to drive at a higher speed. ${ }^{26}$

Vehicle fuel consumption is also associated with the driver's habits. For conventional fuel vehicles, more fuel-efficient driving methods include smooth acceleration or deceleration, keeping the engine at low rotation speed, shutting down the engine when waiting, lowering the maximum speed of travel, and keeping proper tire pressure, etc. Studies performed in Europe and the United States have shown that ecological driving methods can raise the vehicle fuel economy by 5 to 25 per cent. ${ }^{27}$

The transport subsidies are mainly used for those people who use certain means of transportation. For example, economic stimulation schemes such as public transport subsidies and carpooling subsidies are provided to bus passengers and carpooling travellers. Taking Beijing as

25 Feng Xiangzhao, Study on Greenhouse Gases Emission Reduction Strategy of Urban Transport System (China Meteorological Press 2009).

26 ibid.

27 IPCC, Climate Change 2007 (n 21). 
an example, thanks to the bus subsidy policy for card holding passengers, the proportion of citizens taking public transport increased from 26.5 per cent in 2005 to 44 per cent by the end of 2012 .

Parking charge system is also one traffic management measure characterized by economic incentives, and combined with parking restrictions, it is an important factor that affect the traveller's choice of the means of transportation. For example, San Francisco has raised public and commercial parking fees and launched the parking tax to act as part of the "bus priority" policy; Beijing and Shanghai have increased parking fees in the central city.

The demand management mode of park-and-ride hubs has been successfully practised in developed countries and Singapore, and now has taken effect in China. During the period of "11th Five-year Plan", Beijing will construct 26 park-and-ride facilities outside the 4th ring or 5 th rings road, and is expected to implement low price.

In addition, promoting people to change their irrational consumption behaviour through publicity, education and information diffusion is also the typical policy choice of governments around the globe. Given that public transportation and bicycle travel have the characteristics of low cost and low emission (as shown in Figure 4), it is usually the important contents of low-carbon transport development to encourage citizens choosing green travel manners like bicycle travel and public transport.
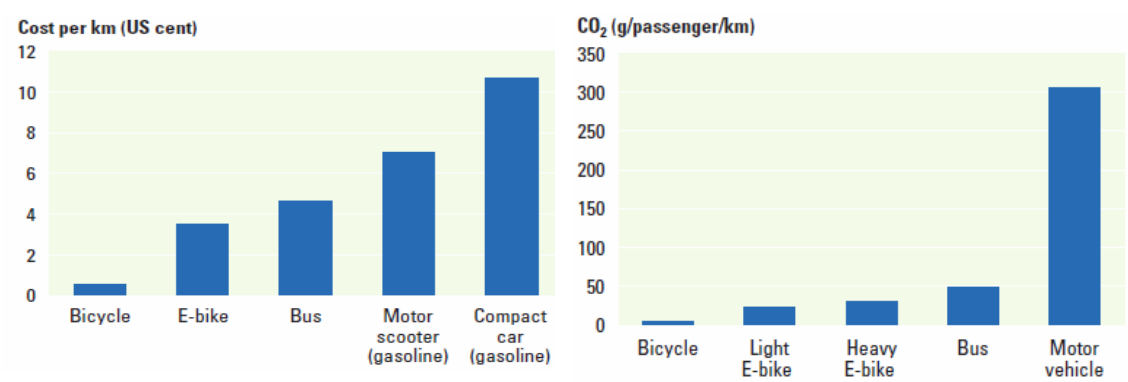

Figure 4. Travel Costs and $\mathrm{CO}_{2}$ Emission of Different Transport Modes in China ${ }^{28}$

In November 2006, the Ministry of Construction called for carrying

28 Bofeng and Xiangzhao (n 5). 
out the Public Transport Week and Car Free Day Activity in China's Cities. ${ }^{29}$ It hoped by that to speed up the construction development of urban public transport and sustainable urban transport system, through the participation of governments, enterprises, media and the public. China's 110 cities responded to the initiative and signed the Letter of Commitment on Public Transport Week and Car Free Day Activity. The first activity was carried out from 16 to 22 September 2007, with a theme of Green Transport and Health. Through these kinds of activities, the transportation energy conservation and emissions reduction was promoted and the urban air quality was improved. For example, on the activity day, $\mathrm{CH}, \mathrm{NO} 2, \mathrm{CO}, \mathrm{CO} 2$ and the inhalable particles emitted from the car exhaust inside the 1st ring road of Kunming city decreased by 55.9 per cent, 45.1 per cent, 32.9 per cent, 15.4 per cent and 20.7 per cent, respectively, compared with those in previous day. ${ }^{30}$

At the same time, the bus priority policy and the concept of green transportation are widely publicized (see Table 3). Based on this, the Kunming city has advocated car free days every month. Shenyang Municipal Environmental Protection Bureau has determined that the first working day of each month is car free day that all official cars will be prohibited from use on that day. The authorities in charge of urban public transportation in Shanghai and Harbin even decided to prohibit using of official cars one day a week. ${ }^{31}$ The Twelfth Five-year National Action Plan for Energy Saving and Emission Reduction released in February 2012 has proposed that all the official cars of the government agencies throughout the country should be "prohibited to use one day a week according to the tail number of their licences, and carry out the official bicycle pilot. Office workers should give up driving one day a month, and the ' 135 ' travel mode is advocated, namely, walk within $1 \mathrm{~km}$, ride a bicycle within $3 \mathrm{~km}$, and take public transport within $5 \mathrm{~km}$ ". Since green travel was initiated in 2006 in China, the participation consciousness of social public has been improved notably as shown in the following data.

29 ibid.

30 ibid.

31 Jiang Yulin, Wu Hongxiang and Shen Yun, Expedite, Effective, Safe and Green - Analysis on Significant Problems of Sustainable Development of China's Urban Public Traffic (Beijing: Science Press, 2010). 
Table 3. Status of Public Participation in Green Travel Initiative

\begin{tabular}{|c|c|}
\hline Time & Marked Events \\
\hline 2006 & $\begin{array}{l}\text { Over } 40 \text { companies in Beijing have promised to encourage } \\
\text { their employees to take green travel in commuter time }\end{array}$ \\
\hline 2007 & $\begin{array}{l}\text { National Green Travel Network was established. } 20 \text { NGOs } \\
\text { promoted green travel in more than } 20 \text { cities across the } \\
\text { country with more than } 1200 \text { enterprises participating in the } \\
\text { initiative that year. }\end{array}$ \\
\hline 2008 & $\begin{array}{l}\text { Green Olympic and Green Travel initiated with } 81,670 \\
\text { people registered online; and } 8,895.06 \text { tonnes of } \mathrm{CO}_{2} \\
\text { emission was reduced. }{ }^{32}\end{array}$ \\
\hline $\begin{array}{l}\text { August } \\
2009\end{array}$ & $\begin{array}{l}\text { Tianping Auto Insurance co., Ltd., in Shanghai bought } 8,026 \\
\text { tonnes of carbon emission reduction targets produced in } \\
\text { Beijing Green Travel Initiative during the } 2008 \text { Olympic } \\
\text { Games to offset the company's carbon emissions since its } \\
\text { inception in 2004, becoming the first carbon counteracting } \\
\text { company in China. }\end{array}$ \\
\hline 2010 & $\begin{array}{l}\text { By the end of December, following "Voluntary Emissions } \\
\text { Reduction Trading Platform of Low-carbon Expo" more } \\
\text { than } 4,500 \text { cases of personal and corporate transactions were } \\
\text { realized with } 26,471 \text { tonnes of voluntary carbon emission } \\
\text { reductions supply being bought. }{ }^{34} \text { Many world expo } \\
\text { pavilions, including the UN pavilion, British pavilion, } \\
\text { Belgian pavilion, Vanke pavilion, Private Enterprise } \\
\text { pavilion, Guangdong pavilion and Heilongjiang pavilion, } \\
\text { have realized successfully the carbon neutral via platform } \\
\text { trading or other ways. }\end{array}$ \\
\hline
\end{tabular}

Source: Zhang Quan et al., 2011

\subsection{The Contribution of Traffic System Management Policies to the Emission Reduction}

In order to reduce $\mathrm{CO}_{2}$ emissions in traffic, the urban traffic system management should focus on the following three aspects, at least: (a) promoting change of transportation mode, (b) enhancing the land use

32 Zhang Quan, Hong Hao \& Dan Dudek (n 24).

33 ibid.

34 ibid. 
and coordination and integration of urban transportation planning, and (c) promoting the application of intelligent transportation system (ITS).

Speeding up the transformation of traffic mode is mainly manifested in developing public transport such as the rail transit and BRT, and increasing the proportion of non-motorized modes of transportation. According to Beijing Traffic Development Compendium (2004-2020), in 2010 , the total operation mileage of Beijing's rail transit network will reach $250-300 \mathrm{~km}$, and by 2015, Beijing will form a rail transit network of 561 kilometres with "three ringy, four horizontal, five vertical and seven radiation lines". ${ }^{35}$ At that time, the proportion of public traffic travel will increase to 45 per cent or above from the current 30 per cent.

In the Netherlands, the proportion of non-motorized travel is as high as 47 per cent, in which bike trips are the main travel mode for a travel distance within 7.5 kilometres, and walk way is the main choice for a distance less than $2.5 \mathrm{~km} .{ }^{36}$ In Britain, about 60 per cent of the residents live within bicycle mileage of 15 minutes away from the station, so it will facilitate the country's bike trip ratio through such measures as providing convenient and safe bicycle parking lots near the station and improving the service level of rail transit carrying bicycle. ${ }^{37}$

Ensuring organic combination of the overall urban planning and the transport planning in the planning level is considered an important step being able to effectively relieve urban congestion and improve the service level of urban traffic system. The organic combination of transportation planning and urban planning in the practice is actually what the TOD (Transit-Oriented Development) actively advocates. TOD is a kind of public transit oriented urban development mode, which emerged from America urban planning idea. Its point is to conduct high density and multi-function development in the city along the large capacity bus lines based on the harmonious and unified planning of urban traffic and urban land. This is to reduce people's daily travel needs, make the most of the travel being completed through public transport, improve the operational efficiency of traffic system, reduce the traffic consumption of energy and lower the carbon emissions level of traffic system.

As far as China is concerned, several big cities such as Beijing, Shanghai, Hangzhou and Shenzhen have begun to explore the practice

35 Bofeng and Xiangzhao (n 5).

36 ibid.

37 IPCC, Climate Change 2007 (n 21). 
of the organic combination of transportation planning and urban planning to a certain extent..$^{38}$ For example, according to The Overall Planning of Beijing City (2004-2020) and Beijing Traffic Development Compendium, Beijing has carried out many special planning formulations including the road transport planning, the rail transit planning, the road network planning, the comprehensive transportation planning, the Olympic special line and bus network planning and operating organization. ${ }^{39}$

The development and application of intelligent technology in urban traffic system will be conducive to the urban traffic system to alleviate congestion, improve the operational efficiency of the system, and ultimately achieve the goals of transport $\mathrm{CO}_{2}$ emissions reduction and promote the sustainable development of urban traffic system. For resolving the common problem of traffic congestion, developed countries such as the United States, Western Europe and Japan have been scrambling to invest significant amounts of money and manpower to carry out largescale research and experiments on road transport intelligence.

At present in some traffic planning of China's large and mediumsized cities, the construction of intelligent traffic system has been identified as medium and long-term development keystones. In Beijing, for example, the 2004-2020 Compendium of Traffic Development Planning proposed the recent development targets, namely, to "Complete the construction of intelligent traffic system demonstration project in 2005, which includes the integrated traffic information platform, the traffic flow information collection, analysis and release system, the intelligent traffic signal control system, the parking guidance system, the highway non-stopping toll system, the intelligent taxi command and scheduling system, the passenger terminal operation scheduling management and passenger information service system, the public tram and bus section operation organization and scheduling system and the public traffic vehicle rescue dispatch system.

\section{CONCLUSION AND RECOMMENDATIONS}

Few policies and practices can be found that directly aim to reduce urban traffic system $\mathrm{CO}_{2}$ emissions at city levels, in China and abroad. These policies and measures designed for ensuring vehicle energy security, easing

38 Bofeng and Xiangzhao (n 5).

39 ibid. 
urban traffic congestion, improving air quality and promoting the urban traffic and urban sustainability have positive impact on urban transport $\mathrm{CO}_{2}$ emission reduction.

Holistic policy reform is important for effectively promoting $\mathrm{CO}_{2}$ emission reduction of urban traffic system. All kinds of policies and measures based on motor vehicle, road, vehicle fuel, travel demand or transportation system of integrated management would be able to reduce effectively the greenhouse gas emissions in traffic system to a certain extent.

Notably, many of the local and international practices have shown that it is not realistic to rely on a single kind of policy to achieve $\mathrm{CO}_{2}$ emission reduction targets of the urban traffic system. Rather, a mix of different policies or comprehensive strategy would lead to significant emission reduction effect. Therefore, further improving and perfecting the $\mathrm{CO}_{2}$ emission reduction policy system on urban traffic system and intensifying the policy innovation should be the strategic choice for effectively achieving targets of urban transport $\mathrm{CO}_{2}$ emission reduction, while promoting the sustainable development of urban traffic, the whole city and the national economy. 